\title{
Technological incorporation in the Unified Health System (SUS): the problem and ensuing challenges
}

${ }^{1}$ Associação Brasileira da Indústria de Química Fina, Biotecnologia e suas Especialidades (Abifina). Av Churchill 129/1102, Centro. 20020-050 Rio de Janeiro RJ Brasil. reinaldo.guimaraes47@ gmail.com

\begin{abstract}
Technological incorporation is a central topic among the concerns regarding health care systems. This paper discusses the role of technology dynamics in health systems' cost increases, suggesting two different approaches - a 'pragmatic-economic' approach and a 'rational-defensive' approach - as guidelines to explain the reasons for this centrality. The paper shows how judicialization results from this situation and discusses two doctrinal views - 'reserve for contingencies' and 'rational use' - as the views that usually guide the debates in the courts and among health policy makers. The paper suggests that the attitude currently prevalent in the Brazilian judiciary system can prejudice the principle of equity by improperly evaluating the principle of integrality. We present a brief genealogy of HTA and a timeline of HTA in Brazil. We also discuss the relevance and the impact of Law 12401/2011, which regulates the principle of integrality in the Unified Health System (SUS) and propose three challenges to the development of HTA actions aiming at technology incorporation in Brazil. Finally, we discuss the entry and the role of private health insurance companies, emphasizing changes in the scenario and in their position.

Key words Technology assessment in health, Technological incorporation in health, Health policies, Judicialization, Collective health
\end{abstract}




\section{Background and current constitution}

According to the International Society for Pharmacoeconomics and Outcomes Research (ISPOR), the Health Technology Assessment (HTA) is defined as: a form of policy research that examines short- and long-term consequences of the application of a health-care technology. Properties assessed include evidence of safety, efficacy, patient-reported outcomes, real world effectiveness, cost and cost-effectiveness as well as social, legal, ethical, and political impacts ${ }^{1}$. This comprehensive definition is interesting primarily because it serves as a research tool in the field of health policy. Moreover, in addition to covering clinic and other disciplines in the health field, this definition extends HTA boundaries to econometrics (with chapters on cost-effectiveness and cost-utility) as well as to social sciences and bioethics. The question that arises is: how has such a recent topic (as we will see later) covered so much ground in such little time? For it is a fact that over the past 25 years, HTA has become a central topic in the management of national health systems throughout the developed, emerging or developing worlds.

This process evolved due to more than one reason. The main reason may have been a 'pragmatic-economic' one, a consequence of the increased impact of health technologies in health spending. The share of technological advancement in health care cost rises is an established fact in most countries ${ }^{2}$. Bodenheimer suggests that the United States, with the highest per capita health expenditure and the largest rise in expenditure costs in the last decade has technology dynamics and lack of rationalization measures as major culprits ${ }^{3}$.

Analyzing the reasons for the relationship between technology dynamics and cost increases, Gelijns and Rosenberg discuss the emergence of a "technological imperative" among health professionals, users and other players. This technological imperative promotes increased competitiveness among those who value the new technology-based launches in the health market. The authors also say that this imperative is articulated by means of three strategies, namely: new technology launches; increased intensity of these technologies; expanded indications for new technologies 4 .

Another approach to the growing importance of the HTA, which could be termed 'rational-defensive', deals with the potential consequences for the health and welfare of humans of using increasingly complex and invasive technol- ogies. In other words, this approach deals with the technological capacity that, on the one hand, looks for promote, prevent, heal and rehabilitate; and on the other hand, sometimes, albeit unintentionally, may damage the health of its users or simply be innocuous. Or else, even though these technologies do generate positive effects, they are not better the effects of other already existing technologies.

In both approaches, one of the most visible consequences of the emergence of this centrality is to shift the debate about technology assessment and incorporation to the world of legal litigation. Currently, in many countries, decisions about the opportunity to evaluate and integrate a technology (and about how to do that) are increasingly being taken in the discursive and doctrinal field of law and not in the corresponding field of health sciences. In other words, this shift tends to place the final word on the evaluation and incorporation of health services and products more and more in the hands of the courts.

From the pragmatic-economic perspective, this debate usually takes place within the framework of greater or lesser acceptance of the doctrine of 'reserve of contingencies' - a conceptual construct developed in Germany in the 1970s and which proposes that "... social rights' effective materialization of services is under the reserve of the State's financial capacity, as they are fundamental rights that rely on services funded by public coffers"s. Adherence to an extended interpretation of this doctrine has been used in courts in various countries, often successfully $y^{6}$. In Brazilian courts, however, it has not found much acceptance.

The 'rational-defensive' perspective gained notoriety when the World Health Organization (WHO) put the topic of 'rational use of health technologies', under discussion. In 1984, the World Health Assembly requested the Director General of WHO to hold a meeting of experts from different stakeholders (governments, the pharmaceutical industry, patient and consumer organizations) to discuss ways to ensure 'rational use of medicines', in particular through better knowledge and information flow, as well as to discuss marketing practices in this field, especially in developing countries. This work group met in Nairobi, Kenya, in 1985 and its report was adopted at the World Health Assembly in $1986^{7}$.

The two approaches regarding the HTA shift to the center of management of health systems follow their own rationales, supported by doctrines and narratives that are internally consis- 
tent. Besides, there has been place for the two approaches, both in the choices made in the making and implementation of health policies, and in litigations to meet demands not included in those choices. Ultimately, the choices of health policy and court decisions today compete --in many countries including Brazil-- for the prerogative of defining what is 'fair' in the provision of health services and products.

Be it by refusing the doctrine of 'possible reserve', be it by underestimating the technical foundations related to 'rational use of health technology', the thesis that we embrace is that the definition usually drawn up in the decisions of the Brazilian courts about 'fair in health', tend to hurt what is perhaps the basic principle of the National Health Service (SUS), namely the pursuit of equity. When it outright refuses the concept of 'reserve of contingencies', it overlooks the real financial impact of the immoderate use of technology in SUS expenditures. When it ignores conceptual and methodological state of the art assessment of the risks posed by technology dynamics, it neglects the real impact of the immoderate use of technologies by the legal claimants for services and products.

\section{Brief genealogy of the HTA}

Studies about evaluation of technologies did not start in the healthcare field. In the United States, still in the 1960s, in the space sciences realm, a proposal was made to create an organization that would assess the political and social impacts of twentieth century technologies. Some years later, within the Congress of the USA, this proposal generated the creation of the Office of Technological Assessment (OTA). This organization lasted from 1972 to 1995, and during President Ronald Reagan's administration it was terminated after being deemed "unnecessary".

HTA is an outcome of national health systems and of health technologies dynamics. Archie Cochrane, in his classic 1971 paper $^{9}$, demonstrates with absolute clarity the relationships between the demands of the British National Health Service and the development of controlled clinical trials in the UK. In relation to the present day, the big difference is that, back then, the focus of evaluations was much more on procedures to be incorporated in the system than on products. It is possible to speculate that this fact reflects the dislocation of health practices, in particular the medical practice, from a dialogical perspective that underlies clinical practice, to a more inter- ventionist approach, based on industrial devices. Put in another way, perhaps the increased intensity of the advancement of health technologies founded in chemistry, electro-electronics and biotechnology in the last quarter of the twentieth century has shifted toward evaluation of products, particularly medication.

On the technical level, as an applied discipline, HTA is a tributary of epidemiology (regarding the methodology) and also of evidence-based medicine at the conceptual level. From epidemiology, HTA imported the important development of controlled trials, and here we must mention Sir Austin Bradford Hill (1897-1991) who belonged to the generation prior to Archie Cochrane. The term 'evidence-based medicine' was created by Gordon Guyatt, a professor at McMaster University (Canada). The term first appeared in medical literature in 1992, in the Journal of the American Medical Association ${ }^{10}$. Its scope - which is not to be discussed herein - is much broader than the HTA, but it is certainly included in the same universe. From another perspective, it should be mentioned that evidence-based medicine underpins the guidance of health professionals (physicians in particular) in the clinical environment. HTA is the constructive and executive basis for health policies. However, the relevant distinction in the application of the two disciplines does not seem sufficient to eliminate the conceptual relationship that governs both, starting with the key position that the tools and the epidemiological reasoning hold in them.

The last quarter of the twentieth century witnessed both the acceleration of technology dynamics and health care cost explosion. During the last decade of the $20^{\text {th }}$ century, due to these two processes, HTA activities flourished and became institutionalized. Among the currently active agencies, the first ones created with a mission to accomplish HTA were of Sweden - Swedish Council on Health Technology Assessment, established in 1987, followed by North American Agency for Healthcare Research and Quality, created in 1999, replacing another with similar mission, founded a decade earlier. The British NICE (National Institute for Health and Care Excellence) was founded in 1999 may very well be the most recognized among national HTA agencies. This acknowledgement is certainly due, to a large extent, to the importance of the public health system in that country. Anticipating a topic we will deal with later, the success of the agencies depends, to a large extent, on public recognition and prestige. In Germany, the Institut 
für Qualität und Wirtschaftlichkeit Gesundheitswesen (IQWiG) was created in 2004, The French agency, Haute Autorité de Santé was also founded in 2004. In Canada, the Canadian agency for Drugs and Technologies in Health was created in 2006, replacing another agency, established in 1990. In 1993 the International Network of agencies for HTA (INAHTA), was created, to gather all national HTA agencies. And in 2003 the International Health Technological Assessment (HTAi) was created, bringing together HTA researchers and health care operators worldwide.

\section{A timeline of HTA in Brazil}

The dates mentioned above show that the global institute ionalization of HTA is very recent. In Brazil, the timeline regarding HTA activities shows a relatively small delay $v i s-a ̀-v i s$ the experiences of the central countries. In a nutshell, the major milestones of this timeline are:

1994 - First National Conference on Health Science and Technology (1st CNCT/S) was held in Brazil. Although dealing with many different topics, the conference established an important conceptual legacy expressed in the proposition that "the policy of science and technology in health is a component of health policy". Actually, in the legislation that created SUS (Law 8.080/1990) ${ }^{11}$, science and technology in health care activities are mentioned among new health system duties. However, different from other multidisciplinary dimensions, this one remained to be developed in terms of executive actions.

1998 - First initiatives of technology assessment in the Ministry of Health $(\mathrm{MoH})$. The initiative concerned health equipment and was enrolled in the activities planned by REFORSUS project, funded by the Inter-American Development Bank (IDB) and the MoH itself.

2000 - Creation of the Department of Science and Technology (DECIT) in MoH. Although the 1st CNCT/S had proposed that the governance of S\&T activities in MoH be led by a secretariat, the creation of DECIT was an important compromise solution to execute the above mentioned conference declaration. Also in DECIT, still in 2000, the first attempts were made for the technological assessment of high-cost medications in order to guide decisions regarding their integration into the SUS.

2003 - Creation of the Department of Science, Technology and Strategic Inputs (SCTIE) in MoH. Almost 10 years after the 1994 conference the recommendation was fulfilled. The secretariat then coordinated three departments - DECIT, DAF (pharmaceutical care) and DES (health economics).

2004 - During the 12th National Health Conference, after HTA was recognized as a strategic tool to support critical management of health technologies, the General Coordination of Technology Assessment in Health (CGATS) was created.

2005 - Rising of lawsuits against $\mathrm{MoH}$ to obtain health products and services from SUS. That year R\$2.4 million were spent to meet these claims, which surged explosively each year. In 2013, expenditure reached $\mathrm{R} \$ 322$ million in $\mathrm{MoH}$ only.

2005 - A Committee was established to prepare a proposal for a National Policy for the Management of Technologies in Health (PNGTS). After three years of work, the proposal was approved by the National Health Council and by the Tripartite Commission, and on November 5th 2009 the ordinance establishing the 2690 PNGTS was published.

2006 - Commission on Health Technology Incorporation (CITEC) was created, within the scope of the Department of Health Care (SAS), made up exclusively by government players. In 2008, CITEC's management was turned over to SCTIE $^{12}$. The importance of this commission lies primarily in the fact that it was an important test for future National Committee for Incorporation of Technologies in SUS (CONITEC), created in 2011.

2006 - Establishment of partnership with INAHTA and Mercosul bodies on HTA.

2007 - First public calls (Tender Bids) for HTA projects, in association with the National Council of Technological and Scientific Development $(\mathrm{CNPq})$.

2008 - Creation of the Brazilian HTA Network (REBRATS) coordinated by $\mathrm{MoH}$ and established by the adhesion of 15 HTA groups scattered throughout universities, medical schools and teaching hospitals. Currently REBRATS brings assembles 66 HTA groups.

2011 - The 8th World Conference on HTA held in Brazil, sponsored by the $\mathrm{MoH}$ and the HTAi.

2011 - Passing of Law 12.401/2011 ${ }^{13}$, which regulates the principle of integrality in the SUS and that, among other provisions, creates $\mathrm{CO}$ NITEC. 


\section{Law 12.401/2011 \\ and HTA challenges in SUS}

Driven by the need to regulate the integrality concept and aiming to establish a legal standard that would mitigate the epidemic of lawsuits initiated in 2005, two bills were put before the Senate, opposite to each other in conceptual terms. Between 2007 and 2010 the $\mathrm{MoH}$ negotiated with the authors (the then senators Flávio Arns and Tião Viana) and later in the House of Representatives, a formula was negotiated to meet a rational view of the concept of integrality. In late 2010 the bill passed in the Congress and Law 12.401 was approved by President Dilma Rousseff in early 2011. Law 12.401 and Decree 7646, which complements the law, establish which goods and services can be provided by the SUS in an environment of great technological dynamism, and under what circumstances they may be provided. Furthermore, a set of duties was defined for the $\mathrm{MoH}$, the most important being the creation of a National Commission for Technology Incorporation into SUS (CONITEC). This committee, which has been operating regularly since 2012 , is made up by representatives of the Civil Society (Federal Council of Medicine and the National Board of Health) and the councils of state and municipal health secretaries (CONASS and CONASSEMS) as well as established routines and procedures in accordance with the new rules established by the law and by the decree.

The CONITEC is definitely a case of success, and from what we know, its success is the outcome of good governance and accountability. Governance is accomplished by complying with the provision in its charter, established by Ministerial Decree (2009/GM/MS, of 13.09.2012) and accountability is rendered by making public every step of their work, available at: http://portalsaude.saude.gov.br/index.php/o-ministerio/ principal/secretarias/sctie/conitec.

According to the site above, in two years of work, CONITEC promoted 85 public consultations, made 84 decisions about claims and decided to acquire 40 products and services.

Despite the good services rendered by the CONITEC, we understand that there are challenges to be faced by the $\mathrm{MoH}$ and the SUS regarding the policy of HTA and the incorporation of technologies in health in Brazil. It is important to highlight that this policy does not depend solely on CONITEC, even if we are to consider only the technological incorporation arm, which is its primary mission. Although there are many oth- er challenges, we selected three of them, namely: political-legal challenge, institutional challenge and technical-conceptual challenge.

\section{The political-legal challenge}

This challenge refers to MoH's ever-larger expenditures with lawsuits and addresses the ongoing epidemic of judicialization of health policy, three years after the enactment of the principle of integrality performed by Law $12.401^{14}$. After intense debates during the second half of the past decade, the climax of which was a series of public hearings convened by the Supreme Court in 2009, the issue of judicialization of health seems to have entered a more "silent" phase, particularly in the context of their primary target - SUS. To be fair, the debates continued in two environments: inside the judiciary system and among the supplementary health insurance companies, which were increasingly required to provide services and products under order by the judiciary system. The relative absence of SUS at this stage of the debate gives off wrong signals because, among other things, it may lead one to believe that, as far as the SUS is concerned, the problem is solved - a perspective which is challenged by the figures. The question that arises is: Considering the legal rules in force which specify under what conditions products and services may or may not be provided to Brazilian citizens, why do judges continue handing down sentences forcing the public health system to provide such products and services?

To address this challenge, we believe it is necessary to start by retrieving some of the debates held in the Supreme Court during the hearings of 2009. First of all, let us consider the ambiguity of the final document, articulated in the vote and opinion by Justice Gilmar Mendes ${ }^{15}$. He fully recognizes SUS' needs to promote distributive justice in an environment of financial resources, which are not only finite, but also scarce (and therefore decisions must be made as to what to provide and under what conditions). According to the Justice, "Forcing the public network to fund any and all health provisions would generate serious injury to the administrative order and would compromise the SUS, further impairing medical assistance to neediest share of the population". At the same time, it acknowledges the possibility "of having the judiciary, or the Administration itself, decide what measures, other than being publicly funded by SUS, should be available to private citizens who, for reasons spe- 
cific to their body, prove that the treatment provided is not effective for them".

Theoretically, we have nothing against the final point in the above quoted paragraph. However, I understand that there are two aspects to be considered to that respect. The first one, regarding the evidence "that the treatment provided is not effective in this case". In order to discuss this aspect, let us go back to the beginning of this text. Within the SUS, who is to have the final word on the use of technology? Is it the one who prescribes, at the individual level, or the health policy, via clinical protocols and therapeutic guidelines? Promiscuous relationships between physicians and the pharmaceutical industry have been reported worldwide. They range from small gifts and advantages, to off-label prescriptions and bribes, with the goal of leveraging the prescription of certain products ${ }^{16}$. Another aspect is medical education in Brazil, which has been the object of substantial criticism. Our physicians, sometimes poorly educated and uninformed, are likely to consider the "advice" given by sales representatives as a kind of - certainly biased - "continuing education".

But even if this were not so, there is another aspect to discuss. All doctors, even those who have exemplary training and who are up to speed, in $100 \%$ of cases act in a moral environment that Max Weber ${ }^{17}$ called the 'ethic of conviction', which should govern the doctor-patient relationship. Health policy makers and managers, however, should operate in an environment that Weber called the "ethic of responsibility". As long as they are supported by appropriate clinical protocols, the latter can get closer to what is 'fair' in health, be it through protecting the health of the patient who makes the 'rational use of technology' be it by defending the 'distributive justice' which must rule the operation of health systems.

The second consideration relates to the epidemic character of situations that should be exceptions. The number of lawsuits and the amounts involved suggest an anomaly and, ultimately, this type of 'legal prescription' may end up becoming the rule - at least as regards the amounts involved. Concerning this matter, we would like to mention a newspaper article ${ }^{18}$ which states that the Lei de Diretrizes Orçamentárias da União (Budget Guidelines Law for the Union) estimates expenditures to the amount of $\mathrm{R} \$ 3.95$ billion for 2014 under the heading 'Fiscal Risks', if the estimated number of lawsuits against the Union in 2014 (there were 18,000 lawsuits in 2013) result in the granting of all claims against the SUS. The same article reports that in 2013 the State of São Paulo was a defendant in 25,700 lawsuits and that the budget in the city of Tubarão (State of Paraná) for basic pharmaceutical care in 2013 was R $\$ 971$ thousand and the municipality paid R\$975.1 in claims decided against the SUS.

Law 12.401/2011 aims to establish limits and conditions to the subjective right to health, laid down as a fundamental right in our Constitution, and does so by regulating the concept of integrality. And, by the way, it does not propose to refer the limit to such right to the 'existential minimum ${ }^{14}$, but to the attempt of establishing what is 'fair' in health ${ }^{19}$. It is understandable that in the absence of such regulation -- which, as already noted, was not performed by the foundational law of SUS (8.080/1990) - and facing a judicial demand for a product or health service - the justice would base his opinion on the constitutional provision and that he would grant the claim. What is not easy to understand is that, since there is a law in force that sets these limits, some magistrates continue to ignore it.

Returning to what we call 'political' challenge, we suspect that the attitude of the judges in the lower courts results from the fact that very little has been made, in doctrinarian-pedagogical terms, to disseminate and explain Law $12.401 / 2011$. And we believe that this is primarily a task for SUS managers, in particular its federal manager. It is a task that holds many difficulties, given the complexity of the Brazilian judicial system. And we suggest two important approaches to accomplish such task. The first one has to do with courts specialized in the specific issue of health. Beside the legal and doctrinal aspects, judicialization encompasses a set of technical sanitary topics, which require specific knowledge on the part of magistrates. And we highlight the fact that on the side of the formulation of litigation this specialization is taking place quite intensely, both by the private lawyers and by the public defenders and prosecutors.

The second approach concerns the essential role of the National Council of Justice (CNJ) in this area. After the public hearings of 2009 the Supreme Court proposed to create a special forum on health, and this $\mathrm{CNJ}$ forum was established in March 2010. In 2014 the CNJ created an 'Organizing Committee of the Health Forum', whose mission is to monitor and resolve legal issues related to health ${ }^{20}$. In addition to members from different judiciary levels, also sitting in the commission are representatives from the $\mathrm{MoH}$ (Department of Health Care), ANVISA 
(the health regulatory agency), ANS (the private healthcare regulatory agency), CONASS and CONASSEMS. This might become an interesting tool to educate on Law 12.401/2011, even though the organizational component representing the $\mathrm{MoH}$ is not one holding CONITEC nor the Department of Pharmaceutical Services (DAF), in charge of managing the SUS pharmaceutical assistance policy, the Department of Science and Technology (DECIT), which coordinates the activities of REBRATS, technical arm of the HTA and the Department of Industrial Complex and Health Innovation (DCIIS), which coordinates health innovation in $\mathrm{MoH}$.

\section{The institutional challenge}

As a result of its good performance, the CONITEC is becoming more and more recognized as an organization operating in the context of its mission. However, this recognition is still limited to the MoH or, at most, to a few instances of SUS, as CONASS and CONASSEMS. International experience shows that the expansion of technical recognition beyond these borders is essential to the institutional consolidation of this agency. For good assessment practices and technological incorporation to thrive in countries that have agencies similar to CONITEC (already mentioned in this text), the recognition of the agency's decisions by the governments and by civil society was of the essence. Even as regards the industry, that as rule does not agree to negative decisions regarding the incorporation of its products, the key is not to adjust to their point of view, but put oneself in a position where, due to transparency and technical competence, recognition is compulsory, even if discordant.

Just as was the case in what we call legal and political challenge, a broader institutional recognition of CONITEC does not depends on the agency alone. This is a task to be performed by the top MoH officials, with the minister of health as its champion. After all, this is about consolidating the position of an agency moving speedily to the center of health policy in Brazil, in direct proportion to the intensification of technological dynamics in the health field.

Nevertheless, the pattern of activity of agencies that deal more directly with assessing and incorporating technology in the $\mathrm{MoH}$, CONITEC and REBRATS have a relevant role in this path towards a broad and permanent institutional recognition. Bearing in mind that this is not done overnight, and that the steps taken so far point in the right direction, we would like to suggest following the example of the principles that govern the actions of the British NICE since its establishment. They are (1) transparency, (2) scientific rigor of the analyses, (3) inclusiveness of social stakeholders, (4) consistency (standardization) of the methodology used in each type of assessment, (5) independence, (6) the ability to review and update its portfolio at certain periods and, (7) the ability to answer on a timely basis ${ }^{21}$.

Still in the institutional terrain, there is a specific challenge related to REBRATS' nuclei, in that most of them are located in teaching hospitals affiliated with universities, other educational institutions and hospitals with teaching and research activities that, as a rule, are publicly managed institutions. Until a few decades ago, these institutions were recognized as the main platform for incorporating new technologies in the country. However, these institutions - with few exceptions - started facing administrative and financial crises, which led to decadence in this as well as in other dimensions. Currently, the leaders in incorporation of technology platforms in Brazil are private hospitals ${ }^{22}$. A clear evidence of this paradigm shift is the creation, by $\mathrm{MoH}$ itself, of a program called PROADI, which refers to quality private hospitals the possibility of partnership in projects of interest to SUS, where HTA is included ${ }^{23}$.

Currently, most of HTA procedures within the REBRATS realm make predominant use of secondary sources of information, especially studies in the field of meta-analyses and other publications. However, it cannot forgo primary sources. Thus, technological capacity of the institutions where their nuclei are located is very important. It is clear that the solution to this problem goes far beyond REBRATS' mandate and even of SUS' policy of technological incorporation. However, it is important to mention this fact as a challenge, as the continuation of this situation could negatively impact its performance.

\section{The technical-conceptual challenge}

Technological incorporation is a process that involves essentially three chapters, which are conceptually, temporarily and methodologically different. They are (1) the selection of items to be evaluated with a view to incorporation; (2) evaluating the technology itself; (3) the final decision on the incorporation.

In Article 19-R, law 12.401/2011 states that "The incorporation, exclusion and change ... [of processes and products] ... shall be accomplished 
by the filing of an administrative process, to be completed no later 180 days from the date the application was filed, in that it may be extended for another 90 calendar days, when circumstances so require". If these deadlines are met, there is no obligation whatsoever to observe the 'line' in that items may be selected for evaluation in an order different from the chronological order they were filed. There is also no obligation regarding an external demand (industry, service provider or operator) for the evaluation of a given product or process. Rather, the decision about what will primarily be evaluated must meet the interests of health policy and not the interests of claimants, in that there is always the possibility of an applicant being a component of SUS, including CONITEC itself. Variables such as general policy priorities, the impact on the budget, the item's potential to improve a specific and the availability of methodologies and analytical evidences are elements to be taken into account in prioritizing, in that all of these aspects are part of the health policy world.

The next chapter, the assessment itself is, rather, a set of strictly technical operations, consisting mainly of epidemiological and econometric methodologies, which use primary sources and, increasingly secondary sources published as systematic reviews. In this chapter, the mention of the Brazilian Cochrane Center (http://www.centrocochranedobrasil.org.br/institucional.html), which is the Brazilian section of the Cochrane Collaboration (http://www.cochrane.org/) is indispensable. It is also necessary to mention the REBRATS, as the Brazilian network collaborators in the field of HTA. "Launched in August 2008, REBRATS seeks to promote and disseminate the area of Health Technology Assessment (HTA) in Brazil. The network establishes a bridge between research, policy and management, providing subsidies for decisions about incorporation, monitoring and abandonment of technologies in the context of their use in health systems. The network is a strategy to make feasible the preparation and dissemination of studies or HTAs which are a priority for the Brazilian health system, contributing to the training and continuing education in this area. It aims to establish general guidelines for the development and standardization of HTA studies; contribute to the validation and quality of studies, and provide methods and tools that allow us to keep track of the technological horizon"24. REBRATS was duly regulated by Ordinance No. 2915 of December 12, 2011 and currently has 66 institutional members in vari- ous stages of development ${ }^{25}$. It should be up to REBRATS to fully comply with the HTA chapter within the process of technological incorporation in SUS.

Finally, the third chapter of the merger process is the final recommendation made by CONITEC to higher authorities in the MoH about the incorporation, exclusion or switch of product or process, based on the evidence provided in the previous step. However, to that decision added considerations on health policy might be added, as the case may be, particularly considerations concerning budget impact, which may not have been adequately addressed in cost-effectiveness studies, prepared during a previous technology assessment. It is clear that 'political' interventions in this phase should be made according to stringent criteria and one can imagine that they will be less frequent as the criteria for prioritization of the item under evaluation have been well explored.

These considerations about the incorporation process, in particular the technical and political balance that permeates it, is suggestive of a conceptual and operational thesis concerning a methodological, administrative and physical separation between administrative agencies that, on the one side, establish priorities and produce recommendations and, on the other, are in charge of HTA itself. Put in simple terms: the thesis holds that those who incorporate do not assess; those who assess do not incorporate.

\section{HTA and incorporation in supplemental health}

Although this text refers basically to the SUS, the ever-greater importance that technological incorporation processes have been gaining in supplementary (private) health systems commands a final comment on this subtopic.

In 2011, in a public debate, Leandro Reis Tavares, then director of standards and qualification of health insurance companies of the ANS (National Agency for Supplementary Health System) was asked about the impact of the inclusion of new procedures in the list of ANS' 'new consumers' from classes $\mathrm{C}$ and $\mathrm{D}$, replied: "the consumer is now a focus of the National Health Agency (ANS). We understand that the list of procedures cannot be any different. Offering technological innovation is one of the components that make up the quality as perceived by the consumer, and the reason why a consumer chooses to invest to

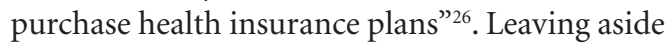


conceptual considerations about health seen as a good related to 'consumers', the director's statements announce an ongoing drama lived by private health insurance companies.

The sentence highlights the importance of technological incorporation as a marketing tool. It deals exactly with what we called, at the beginning of this text, 'technological imperative'. The director links this technological imperative to the "quality as perceived by the consumer, and the reason why a consumer chooses to invest to purchase health insurance". In other words, technology as a marketing tool to promote increased competitiveness in the market for private health plans. If our interpretation is correct, we can say that, from this perspective, the incorporation of technology is ultimately the responsibility of the marketing departments of companies. And if this scenario is true, health insurance company will keep on competing for 'customers' whose family budgets can elastically support an ever-larger 'technological imperative'.

But the scenario has changed with the entry of new, large population segments in the mass consumption market, and now private health plans belong in their wish lists. Unfortunately, however, these new these new desiring consumers do not have pockets deep enough to accommodate all this elasticity imposed by the 'technological imperative', and their employers, co-funding such health plans, are not willing to foot the bill. Thus, there is a growing tension between the technological incorporation as a marketing tool and restrictive policies in the list of services provided by health insurance companies. Turning to the organizational chart, in this new scenario the financial department tends to debunk the marketing one as the ultimate decision maker.

What stands out is that health considerations that universally govern the HTA (effectiveness, cost-effectiveness, etc.) became part of the universe of concerns for health insurance companies only when the once prized 'quality perceived by consumers' derived from the 'technological imperative' was surpassed in corporate strategy by objective consumer's ability to pay for their health plans.

If these considerations cause a certain discomfort in the ethical plane and in the conceptu- al world of 'health as a right', in the factual world there is a positive process going on. In the context of incorporation as a marketing strategy, private health insurance companies used to put pressure on SUS to incorporate technologies that would support inclusions in the list of procedures for such health plans. In the current climate, the attitude has changed and, recalling the two categories that we use at the beginning of the text, both 'pragmatic-economic' approaches (mainly) as 'rational-defensive' (very incidentally) are being adopted by the health insurance companies. The result is that the pattern of incorporation in the supplemental health system is more and more similar to the standard used by SUS. With all the pros and cons that this entails. Among the pros, we have the cooling of incorporation as a marketing tool. Among the cons, the entry of private health plans in the judicialization epidemic. In this regard, there is a growing concern that the entry of health plans companies as defendants may ultimately lead to further litigation against the SUS. There are suspicions that some private health insurance companies may be suggesting and advising policyholders to sue SUS for products and services that they (health insurance companies) are not willing to provide.

\section{Thanks}

To Dr. Flavia Tavares Silva Elias, one of the first champions of HTA in the $\mathrm{MoH}$, for reading and commenting the text prior to publishing and for her collaboration in preparing the timeline of HTA in Brazil.

To the National Institute of Science and Technology - Innovation in Neglected Diseases, on behalf of Professor Carlos Morel, for the permanent and constructive debate environment on relevant themes involving the relationship between technology and health. 


\section{Referências}

1. Eddy D. Health Technology Assessment and Evidence -Based Medicine: What Are We Talking About? Value in Health 2009; 12(Supl. 2):S6-S7.

2. Skinner JS. The Costly Paradox of Health-Care Technology. MIT Technology Review, September 5, 2013. [cited 2014 Apr 22]. Available on: http://www.technology review.com/news/518876/the-costly-paradox-of-health -care-technology/

3. Bodenheimer T. High and Rising Health Care Costs. Part 2: Technologic Innovation. Ann Intern Med 2005; 142(11):932-937.

4. Gelijns A, Rosenberg N. The dynamics of technological change in medicine. Health Aff (Millwood) 1994; 13(3):28-46.

5. Sarlet IW, Figueiredo MF. Reserva do possível, mínimo existencial e direito à saúde: algumas aproximações. Revista de Doutrina da 4 a Região 02.07.2008; Edição 24. [cited 2014 Apr 14]. Available on: http://www.revistadoutrina.trf4.jus.br/index.htm?http://www.revistadoutrina.trf4.jus.br/artigos/edicao024/ingo_mariana. html

6. Wang DWL. Can Litigation Promote Fairness in Healthcare? The Judicial Review of Rationing Decisions in Brazil and England [thesis]. London: London School of Economics; 2013.

7. World Health Organization (WHO). The Rational Use of Drugs. Report of the Conference of Experts. Nairobi, 25-29 November, 1985. [cited 2014 Apr 15]. Available on: http://apps.who.int/medicinedocs/documents/ s17054e/s17054e.pdf

8. O'Donnell JC, Pham SV, Pashos CL, Miller DW, Smith MD. Health Technology Assessment: Lessons Learned from Around the World - An Overview. Value in Health 2009; 12(2):S1-S5.

9. Cochrane A. Effectiveness and Efficiency: Random Reflections on Health Services. London: The Nuffield Provincial Hospital Trust; 1971. [cited 2014 Apr 11]. Available on: http://www.nuffieldtrust.org.uk/sites/files/ nuffield/publication/Effectiveness_and_Efficiency.pdf

10. Smith R, Rennie D. Evidence based medicine - an oral history. JAMA 2014; 311(4):365-367.

11. Brasil. Lei 8.080, de 19 de setembro de 1990. Dispõe sobre as condições para a promoção, proteção e recuperação da saúde, a organização e o funcionamento dos serviços correspondentes e dá outras providências. Diário Oficial da União 1990; 20 set.

12. Novaes HMD, Elias FTS. Uso da avaliação de tecnologias em saúde em processos de análise para incorporação de tecnologias no Sistema Único de Saúde no Ministério da Saúde. Cad Saude Publica 2013; 29(Supl.):S7-S16.

13. Brasil. Lei 12.401, de 28 de abril de 2011. Diário Oficial da União 2011; 29 abr.

14. Guimarães R. Judicialização na saúde: o que há de novo? Cebes 6/3/2014. [cited 2014 Apr 13]. Available on: http://www.abrasco.org.br/busca.php
15. Supremo Tribunal Federal. Relato e voto do Ministro Gilmar Mendes resultante das audiências públicas realizadas pelo referido tribunal em 2009 , relativas ao fornecimento de produtos de saúde pela via judicial. [serial on internet]. [cited 2014 Apr 15]. Available on: http://www.stf.jus.br/arquivo/cms/noticiaNoticiaStf/ anexo/STA175.pdf

16. Oliva MP. Medicamentos en busca de enfermedad. El País 2012 Jul 9; Vida\&artes. [cited 2014 Apr 13]. Available on: http://sociedad.elpais.com/sociedad/2012/07/09/actualidad/1341863741_294998.html

17. Weber M. Política como Vocação. Brasília: Editora da UnB; 2003.

18. Rosa A. União Prevê gastos de R $\$ 3,9$ bi com ações de medicamentos. Valor Econômico - Legislação e Tributos 2014 Apr 15; Notícias do dia. p. E1.

19. Perlingeiro R. Novas perspectivas para a judicialização da saúde no Brasil. Scientia Iuridica 2013; LXII(333):519-539.

20. Conselho Nacional de Justiça (CNJ). Portaria no 40 , de 25 de março de 2014. Cria o Comitê Organizador do Fórum Nacional do Poder Judiciário para monitoramento e resolução das demandas de assistência à saúde. Diário de Justiça Eletrônico/CNJ nº 55 2014; 27 mar. [cited 2014 Apr 16]. Available on: http://www.cnj.jus. br/images/portarias/2014/portaria_n_40_gp_2014.pdf

21. Chalkidou K. Comparative Effectiveness Review Within the U.K.'s National Institute for Health and Clinical Excellence. Issue Brief (Commonw Fund) 2009; 59:1-12.

22. Silveira J. Duelo de jalecos. Revista São Paulo 2011 Oct 30. [cited 2014 Apr 24]. Available on: http://www1. folha.uol.com.br/revista/saopaulo/sp3010201114.htm

23. Programa de apoio ao desenvolvimento institucional do Sistema Único de Saúde (Proadi-SUS). Índice. [cited 2014 Apr 24]. Available on: http://portalsaude.saude. gov.br/index.php?option $=$ com_content $\& v i e w=$ article\&id $=9538 \&$ Itemid $=497$

24. Rede Brasileira de Avaliação de Tecnologias em Saúde (REBRATS). [cited 2014 Apr 22]. Available on: http:// bvsms.saude.gov.br/bvs/folder/rebrats.pdf

25. Rede Brasileira de Avaliação de Tecnologias em Saúde (REBRATS). 70 Instituições-membro da REBRATS. [cited 2014 Apr 22]. Available on: http://200.214.130.94/ rebrats/Membro.php

26. Tecnologia na Saúde Suplementar. Congresso Abramge, 25 de agosto de 2011. Entrevista com diretor da ANS. [cited 2014 Apr 22]. Available on: http://saudeweb.com.br/23661/veja-a-entrevista-com-diretorda-ans/

Article submitted 02/06/2014

Approved 20/06/2014

Final version submitted 22/06/2014 